\title{
Physiological Effects of Insecticides and Fungicide, Applied in the Treatment of Seeds, on the Germination and Vigor of Soybean Seeds
}

\author{
Estevam M. Costa ${ }^{1}$, Bruno M. Nunes ${ }^{2}$, Matheus V. A. Ventura ${ }^{1}$, Roberto K. Mortate ${ }^{3}$, Muriel S. Vilarinho ${ }^{2}$, \\ Rafael M. da Silva ${ }^{4}$, Jaíza F. R. Chagas ${ }^{5}$, Lorena C. A. Nogueira ${ }^{1}$, Bruno H. T. Arantes ${ }^{1}$, \\ Alessandra P. A. Lima $^{6} \&$ Marcio M. Bessa ${ }^{7}$ \\ ${ }^{1}$ Postgraduate Program in Agrarian Sciences-Agronomy, Goiano Federal Institute, Rio Verde, Brazil \\ ${ }^{2}$ School of Agronomy, University of the State of Minas Gerais, Ituiutaba, Brazil \\ ${ }^{3}$ Postgraduate in Agronomy Sustainability in Agriculture, State University of Mato Grosso do Sul, Cassilandia, \\ Brazil \\ ${ }^{4}$ Postgraduate Program in Irrigation in the Cerrado, Goiano Federal Institute, Ceres, Brazil \\ ${ }^{5}$ Postgraduate Program in Plant Production, Federal University of Tocantins, Gurupi, Brazil \\ ${ }^{6}$ School of Agronomy, Evangelical Faculty of Goianesia, Goianesia, Brazil \\ ${ }^{7}$ Postgraduate Program in Geography, Paulista State University, Marilia, Brazil \\ Correspondence: Estevam Matheus Costa, Postgraduate Program in Agrarian Sciences-Agronomy, Goiano \\ Federal Institute, Rio Verde, Brazil. Tel: 55-64-98406-8548. E-mail: estevammcosta@yahoo.com.br
}

Received: October 24, 2018

doi:10.5539/jas.v1 $1 \mathrm{n} 4 \mathrm{p} 318$
Accepted: January 10, 2019 Online Published: March 15, 2019

URL: https://doi.org/10.5539/jas.v11n4p318

\begin{abstract}
The initial protection of plants through the use of insecticides and fungicides has been shown to be efficient for a good management of pests and diseases, however the molecules used in seed treatment have demonstrated a physiological effect on germination and initial vegetative development. The present work had as objective the evaluation of the physiological effect caused by two insecticides and a fungicide on the germination and vigor of the seeds. A randomized block design with six treatments and four replications was used. The treatments were: T1-water; T2-Rocks ${ }^{\circledR}$ insecticide; T3-Insecticide Cruiser $350 \mathrm{FS}^{\circledR}$; T4-Maxim $\mathrm{XL}^{\circledR}$ fungicide; T5-Rocks ${ }^{\circledR}+$ Maxim $\mathrm{XL}^{\circledR}$ and T5-Cruiser $350 \mathrm{FS}^{\circledR}+$ Maxim $\mathrm{XL}^{\circledR}$. The application of the treatments was performed according to the manufacturers' recommendations and the percentage of germination of the seeds was evaluated, on paper and sand roll substrates, the rate of emergence, the total length of seedlings, the electrical conductivity of the imbibition and aging solution accelerated, with a later pattern of germination. The data were submitted to Analysis of Variance and the means were compared by the Tukey test. The results indicated that there were statistically significant differences for all variables except paper germination. The treatments that received the application of the Maxim XL fungicide demonstrated superiority, both in the evaluation of germination in sand substrate, and in the vigor evaluations of seeds and seedlings, while the treatments that received application of Rocks insecticide were inferior to the other.
\end{abstract}

Keywords: thiamethoxam, imidacloprid, Glycine $\max \mathrm{L}$.

\section{Introduction}

Soybean is a widely cultivated crop in several Brazilian regions and is of great economic importance for the country. In order to achieve success in the implantation of the crop as well as high productivity indexes, it becomes indispensable to use high quality seeds. Seed quality is affected as a function of sowing, harvesting, beneficiation, reception, drying and as a result of the genotype-environment interaction in which they were produced.

In order to avoid possible losses due to pest actions, soil and shoot diseases that cause damage to seeds and young plants, the preventive use of insecticides and fungicides in the treatment of seeds is an alternative. This type of treatment has lower costs, less risk of intoxication for the product applicator, faster application efficiency, and greater agrochemical economy. According Pereira et al. (2016), the chemical treatment of seeds is a practice 
that reduces the action of pests and pathogens, providing conditions more favorable to the growth and initial development of plants in the field.

Seed quality reflects directly on crop development, generating high vigor plants, population uniformity, absence of diseases transmitted via seed (Silva, Lazarini, \& Sá, 2010) and greater competitive capacity (Kolchinski, 2003), factors that can directly influence grain yield (Kolchinski, Schuch, \& Peske, 2005). Whereas low quality seeds show typical symptoms of aging, such as low viability, germination reduction and emergence rate, low tolerance to sub-optimal conditions and reduced seedling growth rate (Hamawaki et al., 2002). Seed vigor is the sum of those properties that determine the potential level of activity and performance of a seed or a batch of seeds during germination and emergence of the seedling (Krzyzanowski, Vieira, \& França Neto, 1999, p. 4).

In Brazil, practically $100 \%$ of the soybean seeds are treated with fungicides, $30 \%$ with insecticides, $50 \%$ with micronutrients, also acting as a protection against the fungi and insects complex of the soil, increasing the emergence of the seedlings and their performance to the field, want in the initial establishment or during its vegetative cycle (Baudet \& Peske, 2006). According França-Neto et al. (2015), the estimate is that more than $95 \%$ of the volume of soybean seeds produced in the national harvest of 2014/2015 was submitted to seed treatment, whether it is carried out in the industries and/or in the field.

On the other hand, some insecticides and fungicides can confer, besides the protective effect, certain types of physiological effects, potentiating the vigor of the seeds and seedlings, increasing the initial growth and development of the seedlings with possible reflections on crop productivity due to the fact that these substances to exert bioactivating functions inducing physiological and metabolic changes in plants. In this sense, the use of the insecticide Cruiser 350 FS as seed treatment in soybean, increased vigor, productivity, leaf and root area, more uniform stand, uniformity in emergence and better initial starter (Almeida, 2008). In the corn crop, according to Dan et al. (2010), significant reductions in vigor that were caused by Carbofuran in corn seeds were observed after treatment and storage for a period of 30 days.

Grohs et al. (2012), evaluating the first count of normal seedlings at 7 days after sowing, verified that the applications of Cruiser 350 FS were efficient in stimulating the germination of different rice cultivars. According to these same authors, thiamethoxam as well as gibberellic acid, promoted a stimulus germination that was already expected, because these substances act in different stages of the germinative process, stimulating mainly the activity of key enzymes involved. In the work of Dan et al. (2012) with soybean seeds, the Cruiser 350 FS, Standak, imidacloprid (Gaúcho) and control showed statistically similar values for the evaluation of the rate of emergence, and higher than the treatments that received imidacloprid + thiodicarb (Cropstar), Carbofuran (Furadan) and Acephate (Orthene). According Marchi et al. (2011), the peanut seeds treated with Cruiser, Maxim $\mathrm{XL}$, Maxim XL + Cruiser and control were similar in relation to the germination test.

The objective of this study was to evaluate the physiological quality of soybean seeds treated with Rocks ${ }^{\circledR}$ insecticides (bifenthrin + imidacloprid), Cruiser $350 \mathrm{FS} \AA$ (thiamethoxam) and Maxim XL® (metalaxyl-m + fludioxonil) fungicide on germination and vigor of seeds.

\section{Materials and Methods}

\subsection{Pesticides Treatments}

The experiment was carried out in the seed analysis laboratory of the State University of Minas Gerais and the cultivar used was TMG123RR. Six treatments with four replicates of 50 seeds were evaluated, using the following products: T1-Distilled Water; T2-Rocks ${ }^{\circledR}$ (Bifenthrin + Imidacloprid); T3-Cruiser $350 \mathrm{FS}^{\circledR}$ (Thiamethoxam); T4-Maxim XL ${ }^{\circledR}$ (Metalaxyl-M + Fludioxonil); T5-Rocks ${ }^{\circledR}+$ Maxim XL $^{\circledR}$ and T6-Cruiser 350 $\mathrm{FS}^{\circledR}+$ Maxim $\mathrm{XL}^{\circledR}$. The dosages used were determined according to the manufacturers' recommendations and were as follows: Rocks- $0.50 \mathrm{~L}$ of commercial product for $100 \mathrm{~kg}$ of seeds; Cruiser $350 \mathrm{FS}-0.25 \mathrm{~L}$ of commercial product for $100 \mathrm{~kg}$ of seeds and Maxim XL-100 L of commercial product for $100 \mathrm{~kg}$ of seeds. The volume of the syrup used was $300 \mathrm{~mL}$ of syrup per $100 \mathrm{~kg}$ of seeds for all treatments.

For the application of the treatments a homogeneous syrup was prepared in order to provide the total coating of the seeds. The homogenization of the syrup with the seeds was carried out in plastic bags of $2 \mathrm{~kg}$ capacity. The whole was agitated for 2 minutes in order to homogenize the cover on the seeds and then dried the seeds in the shade for a period of 12 hours at a temperature of $25^{\circ} \mathrm{C}$. The seeds were used soon after these processes.

The variables evaluated were: Standard Germination Test on paper roll type substrate (SGTp), Standard Germination Test on sand substrate (SGTs), Emergency Velocity Index (EVI), Total Length of Seedlings (TLS), Electrical Conductivity of the Soaking Solution (EC) and Accelerated Aging (AA). 


\subsection{Standard Germination Test on Paper Roll Type Substrate (SGTp)}

It was performed in four replicates of 50 seeds each. The seeds were placed to germinate on a "germitest" paper substrate, previously moistened with distilled water using 2.5 times the mass of the dry paper, and kept at $25^{\circ} \mathrm{C}$. The evaluations were performed according to the Rules for Seed Analysis (MAPA, 2009).

\subsection{Standard Germination Test on Sand Substrate (SGTS)}

It was performed in four replicates of 50 seeds each. The seeds were placed to germinate in trays containing substrate of sand type and placed and watered daily. During the experiment the environment was maintained at a constant temperature of $25^{\circ} \mathrm{C}$. The evaluations were carried out according to the Rules for Seed Analysis (Brasil, 2009).

\subsection{Emergency Velocity Index (EVI)}

The test was performed from sowing in containers containing sand as substrate in four replicates of 50 seeds for each sample. The emerged seedlings were counted daily between the emergence and the numerical stabilization moment of the counts. The results were expressed as Maguire (1962).

\subsection{Total Length of Seedlings (TLS)}

Four subsamples of 15 seedlings were used for each treatment. The seeds were seeded on rolls of germitest paper, moistened with distilled water, 2.5 times the dry weight of the paper, and kept in a germinator set at $25{ }^{\circ} \mathrm{C}$ for seven days. The TLS (tip from the main root to the edge of the youngest leaf) was evaluated at 7 days after sowing and the results expressed in centimeters $(\mathrm{cm})$.

\subsection{Electrical Conductivity (EC) of the Soaking Solution}

Four replicates of 50 previously weighed soybean seeds $(0.001 \mathrm{~g})$ were used to soak in plastic cups $(200 \mathrm{~mL})$ containing $75 \mathrm{~mL}$ of deionized water and kept at $25{ }^{\circ} \mathrm{C} 24 \mathrm{~h}^{-1}$ (Hampton \& Tekrony, 1995; Vieira \& Krzyzanowski, 1999). After the imbibition period, the EC was read, using a DIGIMED conductivity meter, model CD 21, with a constant electrode of 1.0. The final results were expressed as "micro Siemens per centimeter per gram" $\left(\mu \mathrm{S} \mathrm{cm}^{-1} \mathrm{~g}^{-1}\right)$.

\subsection{Accelerated Aging (AA)}

For the accomplishment was used gerbox box with horizontal metallic screen fixed in the median position. 0.04 $\mathrm{L}$ of distilled water (to obtain approximately $100 \% \mathrm{RH}$ ) was added to the bottom of each gerbox, and under the screen the seeds of each treatment were distributed to cover the surface of the screen, constituting a single layer. Then, the boxes containing the seeds were capped and incubated at $41{ }^{\circ} \mathrm{C}$, where they remained for 48 hours (Marcos Filho et al., 2001). After this period, the seeds were placed to germinate under the same conditions as the germination test on paper rolls, as previously described.

The data were submitted to Analysis of Variance and the means were compared by the Tukey Test at the 5\% level with the aid of the statistical software SISVAR (Ferreira, 2014).

\section{Results}

The results of the Variance Analysis and Tukey Test (0.05) corresponding to seed germination on paper roll and sand, emergence velocity index, total seedling length, EC and AA are contained in Table 1, where there is no statistically significant difference only for the germination variable in paper roll. 
Table 1 . Results of variance analysis and Tukey Test at the $5 \%$ probability level

\begin{tabular}{|c|c|c|c|c|c|c|c|}
\hline \multirow{2}{*}{\multicolumn{2}{|c|}{ Treatments }} & \multicolumn{6}{|c|}{ Variables evaluated } \\
\hline & & \multirow{2}{*}{$\begin{array}{l}\text { SGTp (\%) } \\
88.50\end{array}$} & SGTs $(\%)$ & \multicolumn{2}{|l|}{ EVI } & TLS $(\mathrm{cm})$ & AA ( $\%$ of germination $)$ \\
\hline 1 & Distilled water & & $87.00 \mathrm{ab}$ & 9.68 & $a b$ & $16.79 \mathrm{~d}$ & $90.00 \mathrm{a}$ \\
\hline 2 & Rocks & 82.00 & $82.00 \mathrm{~b}$ & 8.48 & $\mathrm{~b}$ & $17.40 \mathrm{~d}$ & $80.00 \mathrm{ab}$ \\
\hline 3 & Cruiser 350 FS & 88.50 & $92.50 \mathrm{a}$ & 10.31 & $\mathrm{a}$ & $20.42 \mathrm{c}$ & $84.00 \mathrm{ab}$ \\
\hline 4 & Maxim XL & 92.50 & $87.00 \mathrm{ab}$ & 10.12 & $\mathrm{a}$ & $26.69 \mathrm{a}$ & $89.50 \quad \mathrm{a}$ \\
\hline 5 & Rocks + Maxim XL & 83.50 & $90.00 \mathrm{ab}$ & 9.96 & $\mathrm{a}$ & $25.57 \mathrm{a}$ & $76.50 \mathrm{~b}$ \\
\hline 6 & Cruiser $350 \mathrm{FS}+$ Maxim XL & 93.50 & $95.00 \mathrm{a}$ & 9.88 & a & $23.39 \mathrm{~b}$ & $85.50 \mathrm{ab}$ \\
\hline $\mathrm{F}$ & & $2.86^{\mathrm{ns}}$ & $5.98^{* * 3}$ & $4.67^{* *}$ & & $128.67^{* *-}$ & $3.72^{*}$ \\
\hline & $(\%)$ & 6.22 & 4.24 & 6.17 & & 3.39 & 6.52 \\
\hline & & 12.58 & 8.65 & 1.38 & & 1.69 & 12.61 \\
\hline
\end{tabular}

Note. SGTp: Standard Germination Test on paper roll type; SGTs: Standard Germination Test on sand substrate; EVI: Emergency Velocity Index; TLS: Total Length of Seedlings; EC: Electrical Conductivity of the Soaking Solution; AA: Accelerated Aging.

n.s.: not significant at the $5 \%$ probability level by the $\mathrm{F}$ test; *: significant at the $5 \%$ level by the $\mathrm{F}$ test.

Means followed by the same letter do not differ by Tukey test at the $5 \%$ probability level.

For the germination evaluations on the paper roll substrate (SGTp), no statistically significant difference was observed among the evaluated treatments. On the other hand, in the evaluation of the SGTs, there were statistically significant differences when the Tukey test was applied at $5 \%$ probability, and the treatments that contained the insecticide Cruiser $350 \mathrm{FS}$, applied in isolation or combined with the Maxim XL fungicide were those that obtained the highest percentages of germination of $92.50 \%$ and $95.00 \%$, respectively, whereas the one containing Rocks insecticide, applied without the combination with fungicide, was the one with the lowest percentage of germination $(82.00 \%)$.

Regarding the EVI, for the treatment that received the application of Rocks insecticide, a lower value was observed when compared to the other treatments, which were the treatments that received the application of the other insecticides and fungicide, applied in a way alone or together in addition to the witness.

In the variable TLS, the treatments that received the application of the Maxim XL fungicide were shown to be superior due to a greater stimulus of the growth of the seedlings, being that in the applications of Maxim XL and the combination between Rocks and Maxim XL, were those that obtained the greater lengths of seedlings, with values of 26.69 and $25.57 \mathrm{~cm}$, respectively, whereas the treatment that received the combination between Cruiser 350 FS and Maxim XL, obtained the value of $23.39 \mathrm{~cm}$. The treatments that received only the application of distilled water and the insecticide Rocks did not differ statistically between them and were inferior to the other treatments presenting the TLS of 16.79 and $17.40 \mathrm{~cm}$, respectively.

With regard to AA, whose seeds after the aging process were put to germinate, the evaluations indicated that the germination of the seeds after the process, presented superior results, when they were treated only with distilled water and with the fungicide Maxim XL, whereas the treatment that contained the combination between the insecticide Rocks and the fungicide Maxim XL was what resulted in smaller percentages of germination, $76.50 \%$.

\section{Discussion}

Germination is a factor of great importance, since when the seeds present a low germination percentage, this causes in plant stand faults and a probable loss to the producers. According Brasil (2005), it is defined that the minimum percentage of germination should be $80 \%$. For all evaluated treatments the percentage of germination was satisfactory from the legislative point of view, because in all treatments the germination was superior to $80 \%$ regardless of the substrate used.

The treatments with insecticides and fungicides did not affect the twinning test performed with paper substrate, similarly, Costa et al. (2018) did not observe reductions in the percentage of germination due to the treatment of soybean seeds with fungicides and insecticides. In the work of Lemes et al. (2015), testing three batches of pumpkin seeds with the application of Cruiser $350 \mathrm{FS}$, observed that the percentage of germination was $96 \%$, higher than that found in this study, and the dose did not influence. In other works, Almeida et al. (2009) in 
carrot culture and Almeida et al. (2011) in the rice crop, observed that there was an increase in the percentage of germination in relation to the treatment without application. Salgado et al. (2013), testing Standak, Cruiser 350 FS and Cropstar, observed a percentage of germination with the Cruiser 350 FS of $95.70 \%$, and the insecticides tested were not statistically different from the control. Ludwig et al. (2011) it was verified that soybean seeds treated with Maxim XL, Maxim XL + amino acid PT-4-0 and Maxim XL + Cruiser 350 FS did not reach the minimum standard of germination and were still lower values than control. Tavares et al. (2007) reported that soybean seeds treated with different doses of Cruiser 350 FS did not show changes in germination.

According Dias (2017), sowing soon after treatment with Rocks + nematicide Presence resulted in 90\% germination, except for the treatment with Rocks that was lower. In the same study, the Maxim XL showed 90\% germination, and Maxim XL with a nematicide indicated good germination and emergence performance. In the work of Melo et al. (2010), in the maize culture, observed maximum germination values for Maxim XL and control, being these, superior to treatments with Cruiser 350 FS, Standak, Cruiser 350 FS + Standak and Cruiser $350 \mathrm{FS}+$ Standak + Maxim XL.

The insecticide Rocks reduced the rate of emergence speed of soybean seeds, while the insecticidal Cruiser 350 FS contributed to the increase of this variable. Melo et al. (2010) observed in their work, that there was statistically difference in the treatment Cruiser $350 \mathrm{FS}$, where it presented superiority to the others, followed by the Standak and control. The other treatments were with low values were the Maxim XL, Standak, Cruiser 350 FS + Standak and Cruiser 350 FS + Standak + Maxim XL and Cruiser 350 FS + Standak. In the work of Magalhães (2012) with rice culture, it was observed that the treatment with Maxim XL and Cruiser $350 \mathrm{FS}$ did not show statistically difference in relation to the control treatment. It was also similar to the treatments with Maxim XL and Cruiser $350 \mathrm{FS}$ when used in combination with polymers. The EVI is the most used method to evaluate the vigor of the seed, and the higher the index, the greater its vigor (Magalhães, 2012).

The Maxim XL favored a longer seedling length, in this way, all the treatments that received this insecticide presented superior seedlings to the other treatments. In the work of Cunha et al. (2015) in the soybean culture using Cruiser 350 FS, Avicta Complete, Standak Top, Cropstar, Cruiser Advanced, Sedaxane, Avicta, Maxim XL and witness, the author observed that Cruiser 350 FS, Avicta Complete, Avicta, Maxim XL and witness had similar results and above the other applications. In the work of Dan et al. (2012) with soybean seeds, it was observed that the Cruiser $350 \mathrm{FS}$ and the control showed statistically similar values in relation to seedling length, and superior to the treatments with Standak, Gaúcho, Cropstar, Furadan and Orthene. Marchi et al. (2011), studying combinations of insecticides and fungicides in seed treatment, found that peanut seeds treated with Maxim XL and Cruiser $350 \mathrm{FS}+$ Maxim XL presented higher values than the treatment that received only the Cruiser $350 \mathrm{FS}$ insecticide and the control treatment.

The Maxim XL fungicide and the distilled water treatment presented higher germination percentages after the accelerated aging process, while the same fungicide applied with the Rocks insecticide reduced the germination of the soybean seeds. Ferreira (2016) in his work with seeds of three soybean cultivars, evaluating AA, observed that the Cruiser 350 FS + Derosal Plus, Cropstar + Maxim XL and Cruiser 350 FS + Maxim XL found values statistically superior to the control when they received their respective treatments. In studies carried out by Marchi et al. (2011) the peanut seeds treated with Maxim XL and Cruiser 350 FS + Maxim XL presented values higher than the seeds treated with Cruiser $350 \mathrm{FS}$ and with the control treatment when it came to AA, whereas in the work done by Cunha et al. (2015), the authors noted that the Cruiser Advanced and Standak Top presented the best performance of the Cruiser 350 and the Cruiser Advanced, as well as the Crossover, Cruiser Advanced, Sedaxane, Avicta and Maxim XL, values inferior to the other applications and to the control treatment, whereas the treatments that received application of Cruiser 350 FS and Maxim XL were similar to the control and superior to the others. The application of the Rocks insecticide alone resulted in a decrease in germination and vigor, while the treatments that received application of the Maxim fungicide resulted in superior results when compared to the others.

\section{References}

Almeida, A. S. (2008). Bioativador no desempenho fisiológico de sementes de cenoura (Masters dissertation, Universidade Federal de Pelotas, Pelotas, Brazil).

Almeida, A. S. (2011). The role of bioactivators in the physiological performance of rice seeds. Revista Brasileira de Sementes, 33(3), 501-510. https://doi.org/10.1590/S0101-31222011000300013

Azevedo, L. A. S. (2001). Paradigmas da proteção de plantas com fungicidas. In L. A. S. Azevedo (Ed.), Proteção integrada de plantas com fungicidas (1st ed., pp. 1551-160). São Paulo. 
Baudet, L., \& Peske, T. S. (2006). A logística do tratamento de sementes. SEEDnews, 10(1), 22-25.

Costa, E. M., Nunes, B. M., Ventura, M. V. A., Arantes, B. H. T., \& Mendes, G. R. (2018). Efeito Fisiológico De Inseticidas E Fungicida Sobre A Germinação E Vigor De Sementes De Soja (Glycine max L.). Científic@, 5(2), 2358-260X.

Cunha, R. P., Corrêa, M. F., Schuch, L. O. B., Oliveira, R. C., Junior, J. S. A., Souza, J., ... Almeida, T. L. (2015). Different treatments of seeds on the development of soybean plants. Ciência Rural, 45(10), 1761-1767. https://doi.org/10.1590/0103-8478cr20140742

Dan, L. G. D. M., Dan, H. D. A., Barroso, A. L. D. L., \& Braccini, A. D. L. (2010). Qualidade fisiológica de sementes de soja tratadas com inseticidas sob efeito do armazenamento. Revista Brasileira de Sementes, 32(2), 131-139. https://doi.org/10.1590/S0101-31222010000200016

Dan, L. G. M., Dan, H. A., Piccinin, G. G., Ricci, T. T., \& Ortiz, A. H. T. (2012). Tratamento de sementes com inseticida e a qualidade fisiológica de sementes de soja. Revista Caatinga, 25(1), 45-51.

Ferreira, D. F. (2014). SISVAR: A Guide for its Bootstrap procedures i multiple comparisons. Ciênc. Agrotec, 38(2), 109-112. https://doi.org/10.1590/S1413-70542014000200001

Ferreira, T. F. (2016). Qualidades de sementes de soja tratadas com inseticidas e fungicidas antes e após o armazenamento (Masters dissertation, Universidade Federal de Lavras, Lavras, Brazil).

França-Neto, J. B., Henning, A. A., Krzyzanowski, F. C., Henning, F. A., \& Lorini, I. (2015). Adoção do tratamento industrial de sementes de soja no Brasil, safra 2014/15. Informativo ABRATES, 25(1), 26-29.

Grohs, M., Marchesan, E., Roso, R., Formentini, T. C., \& Oliveira, M. L. D. (2012). Desempenho de cultivares de arroz com uso de reguladores de crescimento, em diferentes sistemas de cultivo. Pesquisa Agropecuária Brasileira, 47(6), 776-783. https://doi.org/10.1590/S0100-204X2012000600007

Hamawaki, O. T., Juliatti, F. C., Gomes, G. M., Rodrigues, F. A., \& Santos, V. L. M. (2002). Avaliação da qualidade fisiológica e sanitária de sementes de genótipos de soja do ciclo precoce/médio em Uberlândia, Minas Gerais. Fitopatologia Brasileira, 27(2), 201-205. https://doi.org/10.1590/S0100-41582002000 200013

Kolchinski, E. M., Schuch, L. O. B., \& Peske, S. T. (2005). Vigor de sementes e competição intraespecífica em soja. Ciência Rural, 35(6), 1248-1256. https://doi.org/10.1590/S0103-84782005000600004

Krzyzanowski, F. C., Vieira, R. D., \& França-Neto, J. B. (1999). Vigor de sementes: Conceitos e testes. Londrina: ABRATES.

Magalhães, M. F. (2012). Desempenho de sementes de milho tratadas com inseticida, fungicida e nematicida durante o armazenamento (Masters dissertation,Universidade Federal de Pelotas, Pelotas, Brazil).

Maguire, J. D. (1962). Speed of germination-aid selection and evaluation for seedling emergence and vigor. Crop Science, 2(2), 176-177. https://doi.org/10.2135/cropsci1962.0011183X000200020033x

MAPA (Ministério da Agricultura, Pecuária e Abastecimento). (2009). Regras para análise de sementes. Secretaria de Defesa Agropecuária. Brasília, DF.

Marchi, J. L., Cicero, S. M., \& Gomes Junior, F. G. (2011). Using computerized analysis of seedlings to evaluate the physiological potential of peanut seeds treated with fungicide and inseticide. Revista Brasileira de Sementes, 33(4), 652-662. https://doi.org/10.1590/S0101-31222011000400007

Marcos Filho, J., Novembre, A. D. C., \& Chamma, H. M. C. P. (2001). Testes de envelhecimento acelerado e de deterioração controlada para avaliação do vigor de sementes de soja. Scientia Agricola, 58(2), 421-426. https://doi.org/10.1590/S0103-90162001000200029

Melo, L. F., Fagioli, M., \& Susstrunk, T. F. (2010). Tratamento de sementes de milho com fipronil e thiamethoxam e sua influência fisiológica nas sementes. Agropecuária Técnica, 31(2), 49-56.

Menten, O. J. (2005). Tratamento de sementes no Brasil. SEEDNews, 1(5), 30-32.

Pereira, L. C., Garcia, M. M., Braccini, A. L., Piana, S. C., Cristina, G., Ferri, T. C. M., ... Marteli, D. C. V. (2016). Efeito da adição de biorregulador ao tratamento industrial sobre a qualidade de sementes de soja (Glycine max (L.) Merr.) aos sessenta dias de armazenamento convencional. Revista Colombiana de Investigaciones Agroindustriales, 2016(2), 15-22. https://doi.org/10.23850/24220582.347

Silva, J. B., Lazarini, E., \& Sá, M. E. (2010). Comportamento de sementes de cultivares de soja, submetidos a diferentes períodos de envelhecimento acelerado. Bioscience Journal, 26(5), 755-762. 
Tavares, L. C., Mendonça, A. D., Zanatta, Z. C. N., Brunes, A. P., \& Villela, F. A. (2014). Efeito de fungicidas e inseticidas via tratamento de sementes sobre o desenvolvimento inicial da soja. Enciclopédia Biosfera-Centro Cientifico Conhecer, 10(18), 1400-1409.

Tavares, S., Castro, P. R. C., Ribeiro, R. V., \& Aramaki, P. H. (2007). Avaliação dos efeitos fisiológicos de thiametoxan no tratamento de sementes de soja. Revista de Agricultura, 82(1), 47-54.

Vieira, R. D., \& Krzyzanowski, F. C. (1999). Teste de condutividade elétrica. In F. C. Krzyzanowski, R. D. Vieira, \& J. B. França-Neto (Eds.), Vigor de sementes: conceitos e testes. Londrina: ABRATES.

\section{Copyrights}

Copyright for this article is retained by the author(s), with first publication rights granted to the journal.

This is an open-access article distributed under the terms and conditions of the Creative Commons Attribution license (http://creativecommons.org/licenses/by/4.0/). 